\title{
DECONSTRUCTIVE HEGEMONY ON THE MARGINAL GENDER AND IDENTITY SEEN IN MAUGHAM'S “THE LOTUS EATER” AND HEAD'S “THE PRISONER WHO WORE GLASSES"
}

\author{
Didimus Estanto Turuk ${ }^{1}$ \\ ${ }^{1}$ Graduate Program of English Language Studies Sanata Dharma University \\ Yogyakarta, DIY, Indonesia
}

Corresponding Author: Didimus Estanto TurukE-mail:@tantosanpio@gmail.com

\begin{tabular}{l}
\hline ARTICLE INFO \\
\hline Received: 2019-09-08 \\
Accepted: 2019-11-27 \\
Published: October 2019 \\
Volume:3 \\
Issue: 2 \\
DOI: \\
https://doi.org/10.33019/lire.v3i2.50 \\
\hline KEYWORDS \\
\hline
\end{tabular}

Hegemony, Deconstruction, Postcolonial, Gender, Abrogation.

\section{ABSTRACT}

Hegemony is one of the Marxist applicative concepts employed during the European colonial period. The colonization constructed a power domination of the European countries toward the colonized. The constructed hegemony performed by the European colonizers is the center of discussion in this essay. This essay aims to examine the hegemony lies within the two short stories which are "The Lotus Eater" by W. Somerset Maugham and "The Prisoner Who Wore Glasses" by Bessie Head through Post-Colonial perspectives and accompanied by the gender perspectives. The constructed hegemony is the major theory of the analysis to scrutinize the oppressions both racial and gender base, however the further analysis is going to scrutinize the abrogation of the hegemony. On scrutinizing the hegemony, Derridian deconstruction is employed to construct the analysis on the abrogation of the European constructed hegemony.

\section{INTRODUCTION}

Hegemony is not simply understood as a domination (Dunkley). Antonio Gramsci's account on the theory presents the bigger scope of the term. His concept of hegemony reveals how the power domination is established longer without physical violence. This Marxist theoretician explains further that it is a medium to maintain the power that turns out more effective to be applied in the long period of time in the more subtle and submissive way (Ashcroft et al). This essay aims to examine the hegemony lies within the two short stories which are "The Lotus Eater" by W. Somerset Maugham and "The Prisoner Who Wore Glasses" by Bessie Head. The two short stories will be examined separately using the accompanied theories.

The discussion of hegemony in Maugham's "The Lotus Eater" will be combined with gender studies' analysis regarding to the oppression identified within the short story is related to the gender discrimination. On the second short stories, "The Prisoner Who Wore Glasses", the identified oppression is built upon a race discrimination and especially about the identity. Due to that fact, the theories of binary opposition and power relation will sharpen the analysis. The hegemony is the major theory of the analysis to scrutinize the oppression, however the further analysis is going to scrutinizing the abrogation of the

\section{(c) (1) (-)}


hegemony. On scrutinizing the hegemony, Derridian deconstruction is employed to sharpen the analysis on the abrogation of the European constructed hegemony.

\section{LITERATURE REVIEW}

The short story consists of two representative binary identities which are the warden and prisoner. These two groups of people are marked with the power relation as one who watches and the other to be watched, one who has the authority and the other one who is subjugated, the one who guard the law and the other who breaks the law. These binary oppositions present no other than the identity depiction of the character on the story represented by Hannetjie-Brille relationship.

The story is taken place in South Africa by the time apartheid law was run over the country, the white minority was on the government in that time. The story presents the strong sense of colonial discourse, the discrimination of the Afrikaans and the underestimated gaze toward them. The discrimination can be traced through the warden assigned for the political prisoners are different from the common prisoners. It has to be white warder indicating there is levels of warder. The binary opposition of the identity of both Hannetjie and Brille signifies the Western domination and hegemony toward the nonWestern country, especially the South Africa, the colonized country. The depiction tries to present the clear cut between the ruler and the ruled. The separation between white and non-White also distributed toward the distribution of job and power relation in the short story. At this point, the constructed hegemony of Western/White domination is well portrayed. It is also told in the story how Hannetjie hits the prisoner, orders them, and punishes them as the form of legitimate action to exercise his power over the Afrikaans, the non-White. Western has been constructed as the ideal form of life in almost every field and for the contrary the avert qualities are distributed to the non-White people. As Huffaker present how the British depict Urabi as an illegitimate oriental dictators form Egypt to legitimate their attach over the land (Huffaker). The narratives are built to preserve the European domination.

\section{METHODOLOGY}

A descriptive qualitative method is the method of this study. It means that on arranging the analysis, the writer used the library research to examine the study. There were two kind of data which would be needed to accomplish this study. The first was the literary work, "The Lotus Eater" by W. Somerset Maugham and "The Prisoner Who Wore Glasses" by Bessie Head, as the primary data which is analyzed in the text. The second was the several writings providing the theories and studies related to the topic, either books or journals. Those data work altogether would help writer to analyze the short stories.

There were three steps to enlarge the study. The steps were collecting the data, analyzing data and drawing the conclusion. The first step, collecting the data was done by reading the text for several time in order to understand and grasp the idea completely. The ideas which were going to grasp and understand were mostly related to the act, behavior, speaking, belief and ability which become the media to analyze the hegemony and its (potential) reverse in the story. The second step was analyzing data by applying the related theories which have already stated in the introduction. The main theory which would be used was the post-colonialism. The writer would correlate constructed hegemony which 
was employed by European colonizer and the hegemony actually performs in this two short stories. The post-colonial theory helped writer to broaden the examination about the hegemony performed in colonial period. The third step was drawing a conclusion about the deconstructive hegemony that happened within these two short stories. The writer also employed the Derridian deconstruction to show how the hegemony can be seen in the reverse way. The use of deconstruction is significant due to its position to neglect the constructed paradigm of the European hegemony which was meant to ease the colonial mission, turns out to be used as the weapon against the colonizer.

\section{RESULTS AND DISCUSSION}

\section{Deconstructive Hegemony on the Marginal Gender in Maugham's "The Lotus Eater"}

\section{The Story Overview}

"The Lotus Eater" by W. Somerset Maugham is a story about someone, which later in the story can be identified as a woman, visited Capri, an island in Italy which is described beautiful and peaceful. The setting of time of the story is mixed between going forward and backward according to the story the characters refer to. The main character, character I, is telling her concern regarding to her friend Thomas Wilson which she admired once and felt pity in the end of the story. The story is about her search to confirm the story regarding to the truth about the life of Thomas Wilson as her (other) friend told her. The character I managed her way to meet, be friended with Thomas Wilson and get the chance to get the confirmation about the story she was led before. This was happened during her first visit to the island. She was amazed toward the spirit and ideology Thomas Wilson has, with all the decision he made for his life and all the plans Wilson has made along the journey. It seems like Thomas Wilson is the one that can live the life everyone wants to which almost affects her to stay in the island and leave her (current) life just as Thomas Wilson did. The story turns to a misery, when ten years later the character I comes back to Capri and her friend tells the current situation of Wilson. She is surprised hearing that after all Wilson's plans that he told ten years ago accomplished, Wilson turns out to lose his spirit and direction. Yet all the brightful and ideal picture of a man can really live the life he wants disappears necessarily.

Deconstructive Reading of The Hegemony on the Marginal Gender in Maugham's "The Lotus Eater"

There are two major characters presented in the story, Thomas Wilson and the character I. These two characters present the two polar gender function and role such as the seeker of truth and the source of truth, the settled wise (fool) man and the unsettled wisdom seeker woman, the speaker and listener. The notions of male domination are clearly portrayed in the first visit of the character I. She is dominated and even inspired by the hegemony of the marvelous Thomas Wilson. This type of notion is a typical gender constructed hegemony. As Ferry presented in his interpretation of masculinity, the typical domination by showing of the inspiration as well as the narration of owning the life is the typical male domination (Ferry). Hegemony is mystified trough out narration or even palpably convince. In the case of Wilson and the character I, the domination is maintained through narration, depiction of the clothes, manner, life style and even the ideology, the concept of true happiness, the use of leisure time as the character I almost convinced. It is important to highlight that the 
domination brings the impact of the hegemony of the male character. The hegemony of Wilson toward the character I, through all the means states previously. The truth about the story she was told before is proven true by her personal encounter with Wilson. It even magnifies the domination of the Wilson's power over the story, as well as the hegemony of the wise male.

The domination of the wise (or can be fool) man, Thomas Wilson, is following the constructed hegemony of male dominated society. It flows smoothly as the common concept man oriented society will accept. However, the hegemony is instantly flipped to the witnesses of the ten years ahead story about Wilson, in the character I's second visit to Capri. The domination of the male, Wilson, is gone. There is no more brightful ideology and beautiful Capri left from him. He has lost his spirit and turned mentally insane. There is no more ideal picture of settled life and the concept of enjoying the leisure as character I admired in her previous visit. If it is compared to the first notion of the story, in character I's first visit, it can be seen that the narration is built upon Wilson own fantasy of a good life. He is depended to the amazedness of people wanting his story. As Hankins says that men need women to confirm their domination (Hankins). Later on the elaboration on sex workers Hankins also highlights that the men's satisfaction is to rule or dominate and depended to woman's obedience or acceptance over it. She wants to highlight that man is less power when the domination is needed to constantly legitimate, the hegemony is constantly reminded (Hankins). From the story, it is observable that the story of the great Thomas Wilson was previously delivered by the character I's friend which then triggers the character I to hear the story directly from the source. It means that the amazedness has been done to character I's friend before. Wilson brings story as his satisfaction, his ideology, the spirit of living the leisure time, as a magnet to feed his satisfaction, to maintain his domination, preserving his hegemony. Here, it is not the hegemony that is being deconstructed but also the story. The narration is not wholly preserving the male domination ideology but presenting the diverse one. He constructed hegemony of male domination is eroded. The woman, the character I, which is not convinced by the narration of the man domination performing by Thomas Wilson and the man which shows himself depended to the amazedness of other person to his belief are two major stand points to deconstruct the gender hegemony in Maugham's "The Lotus Eater".

\section{Deconstructive Hegemony on the Marginal Identity in Head's "The Prisoner Who Wore Glasses"}

\section{The Story Overview}

"The Prisoner Who Wore Glasses" by Bessie Head is a short story about the new warder namely Jacobus Stephanus Hannetjie, a white south African of Dutch decent, performing his duty on the Span One, the prison work for the political prison of South Africa. He is describes as a kind of different warder since he is the first person uses the violence to the prisoners. The warder for this particular Span has been regularly change due to the deception and intelligence of the political prisoners inside. Hannetjie is described to have a clash with Brille, one of the political prisoners. Brillie is twenty years old older than Hannetjie and yet Hannetjie hits him hard for dropping the cabbage, the commodity the prisoners work on. From that moment on, the tension between them became serious and yet Hannetjie was known for his cruelty. The turning point of the story happens when 
Brille caught Hannetjie stealing five bags of fertilizer. It is the moment that Hannetjie follows what Brille wants and all the Span One member want.

He becomes an obedient servant to the prisoners because of the offense he made become a guarantee. In the end of the story, Hannetjie begs Brille to let him go, to release him from the chain of obedience. He promises to do anything because he is desperate and still wants to be with his family. Brille simply said that he and his fellow political prisoners just want him on their side. That statement means that they need Hannetjie to easy their life in the prison, they want his obedience.

\section{Deconstructive Reading of Hegemony on the Marginal Identity in Head's "The Prisoner Who Wore Glasses"}

The short story consists of two representative binary identities which are the warden and prisoner. These two groups of people are marked with the power relation as one who watches and the other to be watched, one who has the authority and the other one who is subjugated, the one who guard the law and the other who breaks the law. These binary oppositions present no other than the identity depiction of the character on the story represented by Hannetjie-Brille relationship. The story is taken place in South Africa by the time apartheid law was run over the country, the white minority was on the government in that time.

The story presents the strong sense of colonial discourse, the discrimination of the Afrikaans and the underestimated gaze toward them. The discrimination can be traced through the warden assigned for the political prisoners are different from the common prisoners. It has to be white warder indicating there is levels of warder. The binary opposition of the identity of both Hannetjie and Brille signifies the Western domination and hegemony toward the non-Western country, especially the South Africa, the colonized country. The depiction tries to present the clear cut between the ruler and the ruled. The separation between white and non-White also distributed toward the distribution of job and power relation in the short story. At this point, the constructed hegemony of Western/White domination is well portrayed. It is also told in the story how Hannetjie hits the prisoner, orders them, and punishes them as the form of legitimate action to exercise his power over the Afrikaans, the non-White. Western has been constructed as the ideal form of life in almost every field and for the contrary the avert qualities are distributed to the non-White people. As Huffaker present how the British depict Urabi as an illegitimate oriental dictators form Egypt to legitimate their attach over the land (Huffaker). The narratives are built to preserve the European domination. The narratives such as books, newspapers, stories and even pictures are in use to manipulate the mind of both culture to accept the european domination, the European hegemony (Huffaker).

The hegemony started to handover when Hannetjie is bounded to the offense he made, stilling the bags of fertilizer. The white hegemony is instantly flipped to the Afrikaans, Brille and his friend. Using the offense as the tread to the warder, they manage to make the warder their tool. The hegemonic discourse is reverse to the domination of the prisoners, the power is in the hand of the Afrikaans now. In the process achieving the domination, the hegemony, the Afrikaans face the phases and use the phase to elevate their bargaining position with white warder. The negotiated identity is change to the superior, no longer under the white non-white relationship but under the possession of the 
knowledge, possession of information about the offense done by the white warder. Identity is negotiable and it depends on the capital of the holder (Pedersen). The constructed hegemony, the white European domination is reverse in this particular circumstances. Previously, in the beginning of the story it is told that the Span One is special. This is a group of the people that is good at cheating and tricking people's mind, which is why there is no black warder assigned to guard them in the first place. The "white" government realizes that ideology, word-view and understanding are a perilous weapon to start the resistance toward the government, to manage the counterwork against the ruler. As Said presented by Dawson, orient is not a geographical area, the physic scope of land but the attitude that the European projects to non-European people including the Afrikaans (Dawson). As Orientalism has a great influence from the Foucault's power and knowledge concept, in this short story the power relation is reverse from the White (half-white) to the Afrikaans or the non-white. The power exercise held by the white warder is now in the hand of the prisoners resulted to the handover of the hegemony from the white to the Afrikaans. The identity as an Afrikaans which is previously marginal, second class and underestimated now gains the hegemony, the domination of power over the white ruler. The constructed European hegemony has been flipped to the hegemony of the marginal Afrikaans performed in Head's "The Prisoner Who Wore Glasses".

\section{CONCLUSION}

Hegemony is the concept used on analyzing the Maugham's "The Lotus Eater" and Head's "The Prisoner Who Wore Glasses". Hegemony as the implementation of the power domination (Ashcroft et al) is seen as the meeting point of these two short stories. Both short stories present the constructed European hegemony, though the issue are different which are gender and race/ identity. The use of Derridian deconstruction is also significant in this essay due to its position to show the abrogation of the constructed concept of hegemony both on gender and race/identity.

In the discussion on the Deconstructive hegemony on the marginal gender in Maugham's "The Lotus Eater", it is hard to find the postcolonial notion. It requires an adjustment on gender studies to finally come to the discussion of the hegemonic notion between genders that brings the notion of post-colonialism. It is hard to find the colonial discourse or even post-colonial phenomena in the story since there are no colonial or postcolonial setting, name, racism, discrimination, ambivalence or ideology portrayed explicitly in the short story. Then the gap provided to be elaborated is on the gender domination. The gender of the character I is also not clearly stated, but from the gestures of using hells and drinking wine only between the two of them, it can be concluded that the character $\mathrm{I}$ is a woman. The power domination spread over the story, the character Thomas Wilson that is being glorified and looked up to indicate the man dominated society and male hegemony constructed within the short story. Then, using derridian deconstruction, the hegemony is reversed and the another hegemonic power is revealed.

"The Prisoner Who Wore Glasses" by Bessie Head is easier to examine since there is already the historical background and clear oppression within the short story. The short story portrays an oppression and discrimination of the white African to the black African. There is already a clear binary opposition described in the short story. The hegemony in the story also seen in both using the concept and aperture. The abrogation also presented in the short story by the reverse power domination. The White European hegemony is easily 
LIRE JOURNAL (JOURNAL OF LINGUISTICS AND LITERATURE)

P-ISSN: $\underline{2598-1803}$

E-ISSN: 2581-2130

Volume 3 Number 2 October 2019

countered in this short story. Derridian deconstruction is still be used on reversing the European constructed hegemony from the European domination to the Afrikaans domination.

\section{ABOUT THE AUTHOR(S)}

The author is the student of Graduate Degree from Sanata Dharma University in Yogyakarta, Indonesia.

\section{REFERENCES}

Bill A., Gareth G., \& Helen T. (2007). The Post-Colonial Studies The Key Concepts. London: Routledge.

Dawson, A. (2013). "Edward Said's Imaginative Geographies and The Struggle for Climate Justice." College Literature, vol. 40, no. 4, 2013, pp. 33-51., www.jstor.org/stable/24543185.

Dunkley, D.A. (2011). "Hegemony in Post-Independence Jamaica." Caribbean Quarterly, vol. 57, no. 2, 2011, pp. 1-23. JSTOR, www.jstor.org/stable/23050526.

Ferry, P. (2012). “An Interpretation of Masculinity in Manhattan: Reading Jed Rubenfeld's The Interpretation of Murder." Atlantis, vol. 34, no. 2, 2012, pp. 49-66. JSTOR, www.jstor.org/stable/26453024.

Hankins, S. (2015). “'I'm a Cross between a Clown, a Stripper, and a Streetwalker': Drag Tipping, Sex Work, and a Queer Sociosexual Economy." Signs, vol. 40, no. 2, 2015, pp. 441-466. JSTOR, www.jstor.org/stable/10.1086/678149.

Huffaker, Shauna. (2012). "Representations of Ahmed Urabi: Hegemony, Imperialism, and the British Press, 1881-1882." Victorian Periodicals Review, vol. 45, no. 4, 2012, pp. 375-405., www.jstor.org/stable/43663144.

Pedersen, Anne-Marie. (2010). "Negotiating Cultural Identities through Language: Academic English in Jordan." College Composition and Communication, vol. 62, no. 2, 2010, pp. 283-310. JSTOR, www.jstor.org/stable/27917897. 